\title{
Cross-sectoral and trans-national interactions in national-scale climate change impacts assessment-the case of the Czech Republic
}

\author{
Lamprini Papadimitriou ${ }^{1}$ (D) - Miroslav Trnka ${ }^{2} \cdot$ Paula Harrison $^{3} \cdot$ Ian Holman ${ }^{1}$
}

Received: 12 March 2019 / Accepted: 30 August 2019 / Published online: 16 September 2019

(C) The Author(s) 2019

\begin{abstract}
Assessing the combined impacts of future climate and socio-economic change at the country level is vital for supporting national adaptation policies. Here, we use a novel modelling approach to study the systemic impacts of climate and socioeconomic changes on the Czech Republic, taking account of cross-sectoral interactions between agriculture, water, forestry, land-use and biodiversity, and, for the first time, trans-national interactions. We evaluate the national-level baseline results, scenario-neutral model sensitivities, and climate and socio-economic scenario impacts using a European-scale integrated modelling tool. Consistently across most climate and socio-economic scenarios, the Czech Republic is projected to have increasing importance as a crop-growing region in Europe, due to an increased competitive advantage within the continent. Arable land in the Czech Republic expands, at the expense of livestock farming and forestry, with associated impacts of increased water scarcity and reduced biodiversity for the country. Accounting for trans-national interactions in national-scale assessments provides more realistic assessments of impacts and helps to identify the changing role of the country within its regional and continental domain. Such improved understanding can support policy-makers in developing national adaptation actions that reduce adverse impacts and realise opportunities.
\end{abstract}

Keywords Shared socio-economic pathways $\cdot$ Representative concentration pathways $\cdot$ Adaptation $\cdot$ Models

\section{Introduction}

Climate change will lead to widespread and diverse (positive and negative) impacts across human and environmental systems (IPCC 2014). The climate change experienced in a location will depend on global-scale (e.g. emissions of greenhouse gases - van Vuuren et al. 2011; van Vuuren and Carter 2014)

Communicated by Marc J. Metzger

Electronic supplementary material The online version of this article (https://doi.org/10.1007/s10113-019-01558-9) contains supplementary material, which is available to authorized users.

Lamprini Papadimitriou

lamprini.papadimitriou@cranfield.ac.uk

1 Cranfield Water Science Institute, Cranfield University, Cranfield, Bedfordshire MK43 0AL, UK

2 Global Change Research Institute of the Czech Academy of Sciences, Belidla 986/4, 60300 Brno, Czech Republic

3 Centre for Ecology \& Hydrology, Lancaster Environment Centre, Lancaster LA1 4AP, UK to regional- and local-scale factors (such as interactions with orography and proximity to oceans). Consequently, the changes in climate projected across Europe vary between the oceanically influenced regions of northwest Europe to the continental climates of eastern and central Europe (Kovats et al. 2014; EEA 2018).

However, climate change will not occur in isolation and will be accompanied by socio-economic changes, such as in population, economies, societal and personal values, governance, and technology (O'Neill et al. 2017; Kok et al. 2018). The impacts of these highly uncertain socio-economic futures on key sectors such as water resources management and agriculture can be more significant than those due to climate change (Holman et al. 2017; Harrison et al. 2018).

The nations of Eastern and Central Europe have experienced major socio-economic changes over the past 30 40 years as they have transitioned to democratic nations and, in many cases, membership of the European Union. Nevertheless, economic convergence with western European countries is an ongoing process that will take many decades; so continuing socio-economic change is probable, meaning 
that understanding the combined impacts of future climate and socio-economic change is important for informing national adaptation policy.

We focus on the Czech Republic in central Europe, a region where future precipitation trends are uncertain (Kjellström et al. 2011; Kovats et al. 2014). Climate change in the Czech Republic is expected to lead to wetter winters and drier summers (Kyselý et al. 2011; Stepanek et al. 2016), more frequent extreme rainfall events (Kyselý and Beranová 2009; Kyselý et al. 2011; Rulfová et al. 2017), decreased spring and summer runoff (Hanel et al. 2012), increased flood damages (Rojas et al. 2013), increased pest pressures (Eitzinger et al. 2012), increased risk of land degradation (Trnka et al. 2016), changing crop suitability (Trnka et al. 2009; Machar et al. 2017) and crop yields (Trnka et al. 2004; Eitzinger et al. 2012), changing species suitability (e.g. Lučan et al. 2013; Kolář et al. 2017), and increased urban heatwave impacts (e.g. Lorencová et al. 2018).

Whilst there have been previous national climate change impact and vulnerability assessments in Europe (reviewed in EEA 2018), these have three key common limitations. Firstly, they tend to focus on the impacts of climate change alone, with quantitative scenarios of socio-economic change being used in less than half of the national assessments. Secondly, they have a sectoral or multi-sectoral (rather than inter-sectoral) perspective (EEA 2018) that neglects systemic interactions that can moderate or exacerbate impacts (Harrison et al. 2016). Finally, they tend to focus on the use of existing literature and expert workshop/interviews, with less than half of assessments taking a co-ordinated modelling approach. Therefore, the systematic and quantitative assessment of the cross-scale interactions or teleconnections that affect within-country impacts of climate change (e.g. due to agricultural trade, species migration, population (im)migration, transboundary river basin flows) is unlikely to be fully accounted for.

The aim of this paper therefore is to develop an improved understanding of the systemic impacts of climate change and socio-economic change on the Czech Republic, taking account of cross-sectoral interactions between agriculture, water, biodiversity, forestry, and land-use. Unlike previous studies, the trans-national interactions between the Czech Republic and the rest of Europe were explicitly considered. In doing so, we apply a spatially distributed European-scale integrated modelling tool (the IMPRESSIONS Integrated Assessment Platform2) but, for the first time, evaluate the impacts at a national, rather than continental, scale.

\section{Methods}

\section{IMPRESSIONS Integrated Assessment Platform (IAP2)}

The IMPRESSIONS Integrated Assessment Platform (IAP2), a further development of the widely published CLIMSAVE
IAP (Harrison et al. 2013, 2015) to include the latest climate (dynamically downscaled CMIP5 climate model projections using Representative Concentration Pathways) and socioeconomic scenarios (Shared Socio-economic Pathways), integrates a suite of sectoral models (water resources, crops, forestry, land-use allocation, species, floods) within a web-based platform. The IAP2 uses $10 \operatorname{arcmin} \times 10$ arcmin (approximately $16 \mathrm{~km} \times 16 \mathrm{~km}$ ) grid cells across Europe (the EU28 plus Norway and Switzerland), although multiple land-uses are simulated within each cell. The models use average monthly to average annual input variables to simulate a wide range of impact and ecosystem service indicators. When simulating impacts, the models do not account for adaptation, with the exception of the land-use allocation model which includes autonomous adaptation to climate change due to changing crop yields. The linked models have been thoroughly validated and assessed through sensitivity (Kebede et al. 2015; Fronzek et al. 2018) and uncertainty analysis (Dunford et al. 2014; Brown et al. 2015). The model has been used in numerous climate change impacts and adaptation studies (Dunford et al. 2015; Harrison et al. 2016, 2018; Holman et al. 2017). A more detailed description of IAP2 is given in the Electronic Supplementary Material (ESM).

\section{Exploratory scenarios of climate change and socio-economic change}

The IAP2 includes three Representative Concentration Pathways (RCP 2.6, 4.5 and 8.5) and four European Shared Socio-economic Pathways (SSP 1, 3, 4, and 5) out to 2100. For each RCP, multiple CMIP5 global climate model (GCM) runs that had been dynamically downscaled using Regional Climate Models (RCMs) and are available within the Coordinated Regional Climate Downscaling experiment (CORDEX, Jacob et al. 2014) are used (Table S1 of ESM) to represent future climate model uncertainty in Europe (Madsen et al. 2016).

European versions (Kok et al. 2018) of four of the five global SSPs of O'Neill et al. (2017) capture the low and high challenges to both mitigation and adaptation. SSP2 (Middle of the Road) was omitted as a scenario lacking a distinct identity, as it is characterised by moderate changes on almost all its elements and intermediate challenges to both adaptation and mitigation (O'Neill et al. 2017; Kok et al. 2018). Quantified national values of population and GDP variables were provided from the global SSP database v1.0 (https://secure.iiasa.ac.at/web-apps/ene/SspDb/), whilst remaining scenario inputs were quantified using stakeholder estimates of change (See Table S2 and Table S3 of ESM and Pedde et al. (2018)). The European SSPs and their quantifications, which do not account for any adaptation to climate change, reflect contrasting but plausible futures to 2100 : 
- SSP1-A high commitment to sustainable development through global cooperation results in reduced inequality and less resource intensive lifestyles. Investment in health and education and strong social cohesion enables communities to become more resilient to impacts and risks.

- SSP3-Economic problems and increasing demand for resources lead to conflict between and within regions of Europe. Social break-down, declining living standards, and reducing long-term economic planning lead to a carbon intensive and highly unequal Europe.

- SSP4 Global power increasingly belongs to a political and business elite who drive innovation and a high-tech green Europe alongside rising inequalities between the rich and poor.

- SSP5-People place increasing faith in competitive markets, innovation, and participatory societies to produce rapid technological progress and development of human capital but lack environmental concern, as the development depends on fossil fuels.

\section{Model runs and analyses}

The IAP2 was run for:

- Baseline (1 run): The baseline is represented by the CRU climatology for 1961-1990 (New et al. 2002) and socioeconomic settings for 2000-2010.

- Sensitivity analysis (110 runs): combinations of changes in annual average temperature $\left(-1{ }^{\circ} \mathrm{C}\right.$ to $+11^{\circ} \mathrm{C}$ in steps of $\left.1{ }^{\circ} \mathrm{C}\right)$ and precipitation $(-60 \%$ to $+40 \%$ in steps of $10 \%$ ) following (Fronzek et al. 2018).

- Climate change scenarios alone (30 runs): RCP2.6, 4.5, and 8.5 for three to four GCM-RCMs and baseline socioeconomic settings (Table S1) for the 2020s, 2050s, and 2080s time-slices.

- Combined climate and socio-economic scenarios (99 runs): selected combinations of RCPs, GCM-RCMs, and SSPs (Table S1) for the 2020s, 2050s, and 2080s timeslices.

The simulated outputs for the Czech Republic for the baseline have been evaluated against CORINE land-cover (2000) and national land-cover statistics (2010), national crop areas (2010), and average annual crop yields for NUTS3 regions (for 2000-2017) from the Czech Statistical Office (2018). The sensitivity analysis runs were used to develop Impact Response Surfaces (IRS) for those grids within the Czech Republic, the larger 'Continental' bioclimatic classification region (Metzger et al. 2005) in which the Czech Republic lies, and the entire European region (Fig. S1). The IRS show the relative change in the selected IAP2 indicators relating to land-use, cropping, water, and biodiversity with respect to the $0{ }^{\circ} \mathrm{C}$ temperature change and $0 \%$ precipitation change simulation. These were evaluated to understand the relative sensitivity of the indicators within the Czech Republic to systematic changes in climate variables compared with the surrounding region and the continent. The IRS methodology allows us to conduct a "scenario-neutral" sensitivity analysis of the effects of temperature and precipitation changes. The methodology was not extended to socio-economic inputs, as these are examined in a scenario context in conjunction with the changing climate. Finally, we analysed simulated impacts under climate change-only and climate and socio-economic change to explore the changes within the selected output variables over time, by using multiple RCPs and climate models to account for the uncertainties in future emissions and climate model simulations.

\section{Results}

\section{Evaluation of baseline performance in Czech Republic}

The land-use classes simulated by the IAP2 were compared with the national land-cover data and the CORINE land-cover dataset for the baseline period (Fig. 1a). There is excellent agreement between the simulated and observed urban, agricultural, forest, and unmanaged land areas, although there are differences in the proportions of arable and grassland, with the IAP2 appearing to over-estimate grassland at the expense of arable areas. These differences can be attributed to the uncertainty in classifying grasslands of different types and management intensities. For example, the Czech national data only differentiate permanent grasslands (which may be extensively or intensively managed), with temporary or ley grasslands being included within their arable class (unlike the IAP2). Similarly, differences in class definition (Pérez-Hoyos et al. 2012), uncertainties inherent to satellite-based datasets (De Meij et al. 2018), and uncertainties relating to the derivation of ground-based and satellite-based products (Frolking et al. 1999) contribute to the differences with the CORINE estimates. The CORINE classes used for aggregation to IAP2 outputs can be found in Fig. S2 of ESM.

Simulated crop areas and yields are compared with respective national data (Fig. 1b, c). We focus on four crops (wheat, rapeseed oil, barley, forage maize) that are the most widespread crops in the Czech Republic, and together cover about $50 \%$ of total agricultural area and about $70 \%$ of arable area. There is very good general agreement in the simulated and reported national crop areas (Fig. 1b). The reported median average annual yield for wheat and barley is within the interquartile range of the simulations among 13 NUTS regions (Fig. 1c). For oilseed rape and forage maize, although the above condition is not met, the model performance is still comparable with the reported yields, with $\sim 15 \%$ 

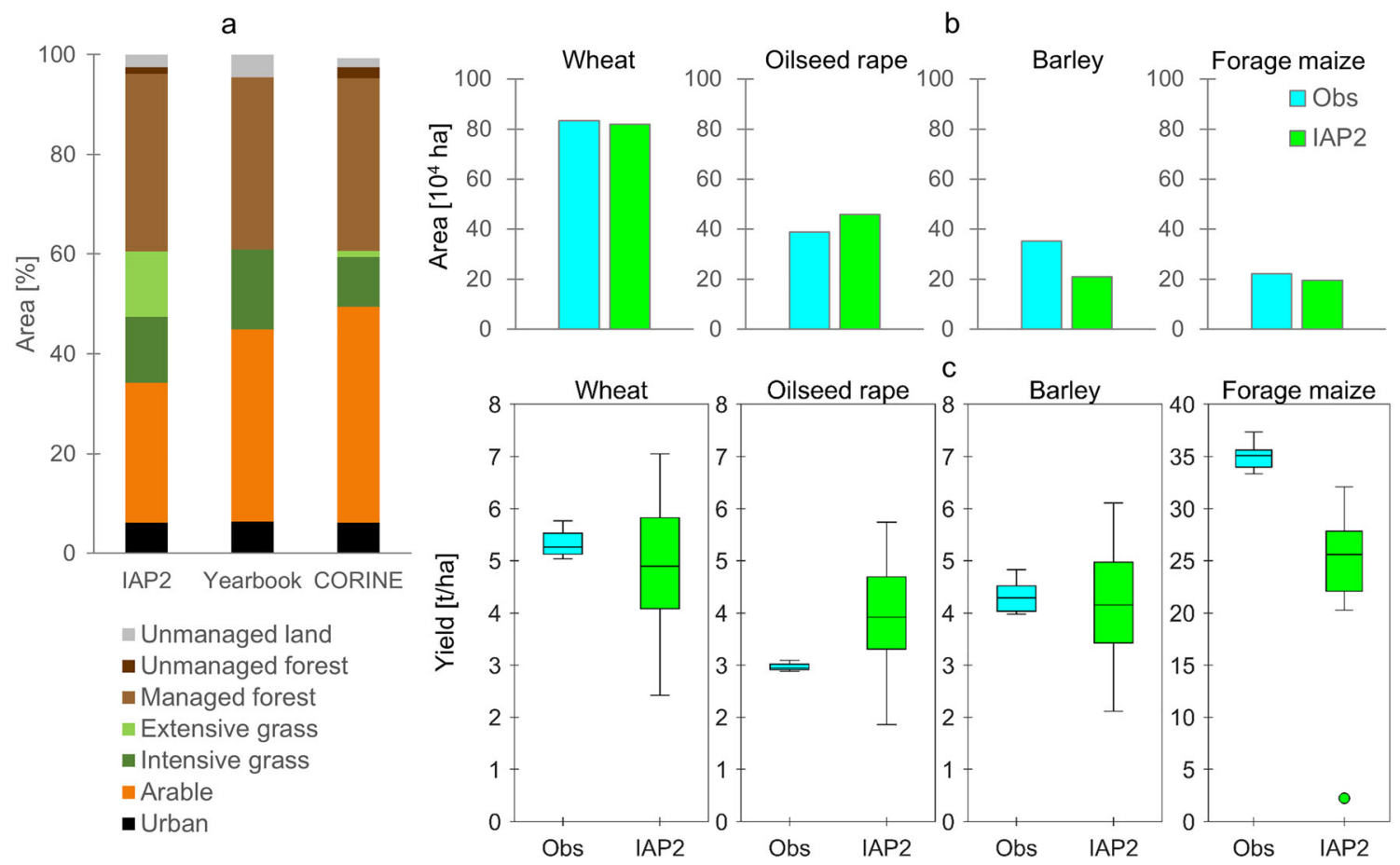

Fig. 1 (a) Land-use classification for Integrated Assessment Platform 2 (IAP2) (baseline) and data from the Yearbook (2010) and Corine (2000) for the Czech Republic, $(b, c)$ simulated and reported crop areas and yields for the four most extensive crops in the Czech Republic: (b) Observed (2010) and simulated (baseline) crop areas and (c) Boxplots of average

annual crop yield [t/ha] within the NUTS3 areas. Each boxplot consists of 13 values (one per NUTS3 region), with the outliers of the sample shown as dots outside the boxplot. Observed values are the averages of the 2000-2017 period

underestimation and $\sim 33 \%$ overestimation, respectively. Nevertheless, it is apparent that the range of reported average annual yields across the 13 NUTS regions in the Czech Republic is much narrower than for the baseline simulation, indicating greater spatial variability in the modelled crop yields (Fig. 1c). The values of simulated and observed crop yield for each of the 13 NUTS regions are given in Tables S4 and S5 of ESM respectively.

\section{Sensitivity analysis}

The results of the sensitivity analysis are shown as scenarioneutral IRS for a number of key outputs on crop yield, water use, biodiversity, and land-use for the Czech Republic, the Continental region, and Europe (Fig. 2). For the Czech Republic, simulated wheat yield decreases with temperature increases and all variations in precipitation. The IRS is similar to that of the Continental region, but shows generally larger yield decreases at high temperature increases than Europe, reflecting the reduced climatological range (and therefore lower variability in yield response to changes) at the smaller scales. The area of arable land generally increases with increasing temperature, which might seem counterintuitive given the decreasing yields and therefore gross margin (as costs remain constant). However, as yields decline in the Czech Republic and Europe, the area of arable land in
Europe has to expand in order to meet the constant food demand. The larger arable area increases in the Czech Republic of up to $40 \%$ relative to the baseline compared with the Continental region and Europe as a whole indicate that the Czech Republic (despite yield decreases in crops such as wheat) has a relative competitive advantage under these climate conditions.

The changes in water availability and the Water Exploitation Index (WEI) (Fig. S3 of ESM) are highly sensitive to changes in precipitation with little sensitivity to temperature changes, due to the strong soil water control on actual evapotranspiration. Irrigation usage (Fig. 2) strongly increases for all temperature increases and with decreased precipitation in the Czech Republic reflecting the increased yields and gross margins of some irrigated crops compared with rainfed crops under conditions of increasing aridity combined with sufficient water resources to support increased irrigation. These increases are greater than in the Continental region and Europe as a whole reflecting the increased arable area and greater aridity. There is a gradual reduction in the number of species (Fig. 2) as temperature increases and precipitation decreases leading to major species loss for extreme levels of warming $\left(>5{ }^{\circ} \mathrm{C}\right)$ and drying $(<-50 \%)$ of more than half of simulated number of species. This arises from the combination of substantial changes in suitable climate and the dramatic land-use changes associated with agricultural expansion 
Fig. 2 Impact response surface (IRS) analysis for (a) the Czech Republic, (b) the Continental region, and (c) the European domain. Precipitation changes are shown on the $y$ axis and temperature changes on the $x$ axis of each plot. Contour values refer to the percentage change in the indicator relative to the baseline a. Czech Republic
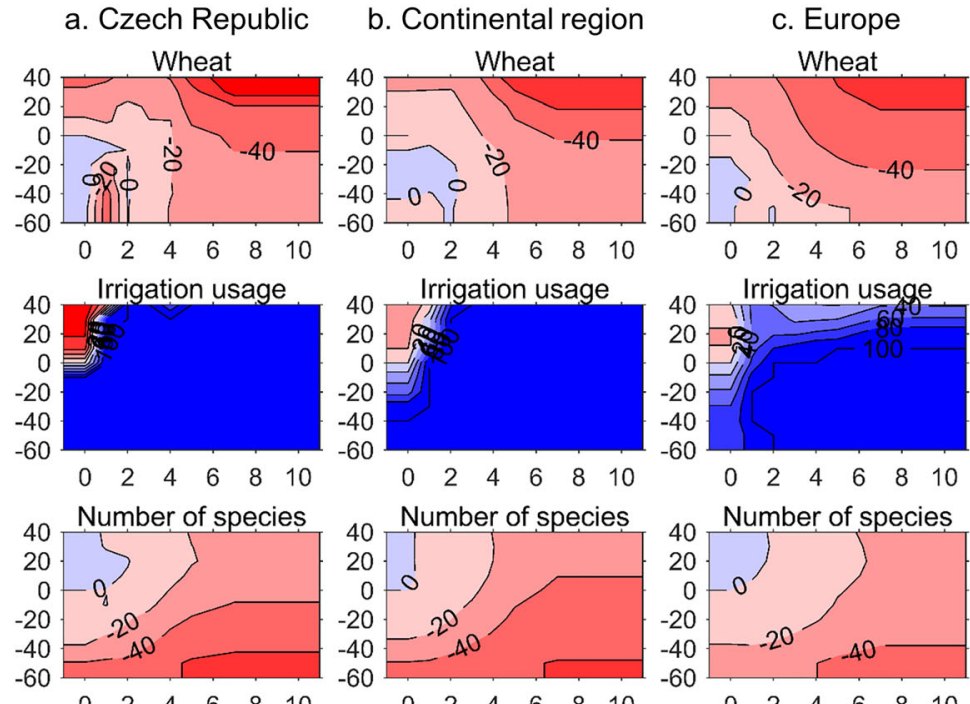

$\begin{array}{llllll}0 & 2 & 4 & 6 & 8 & 10\end{array}$
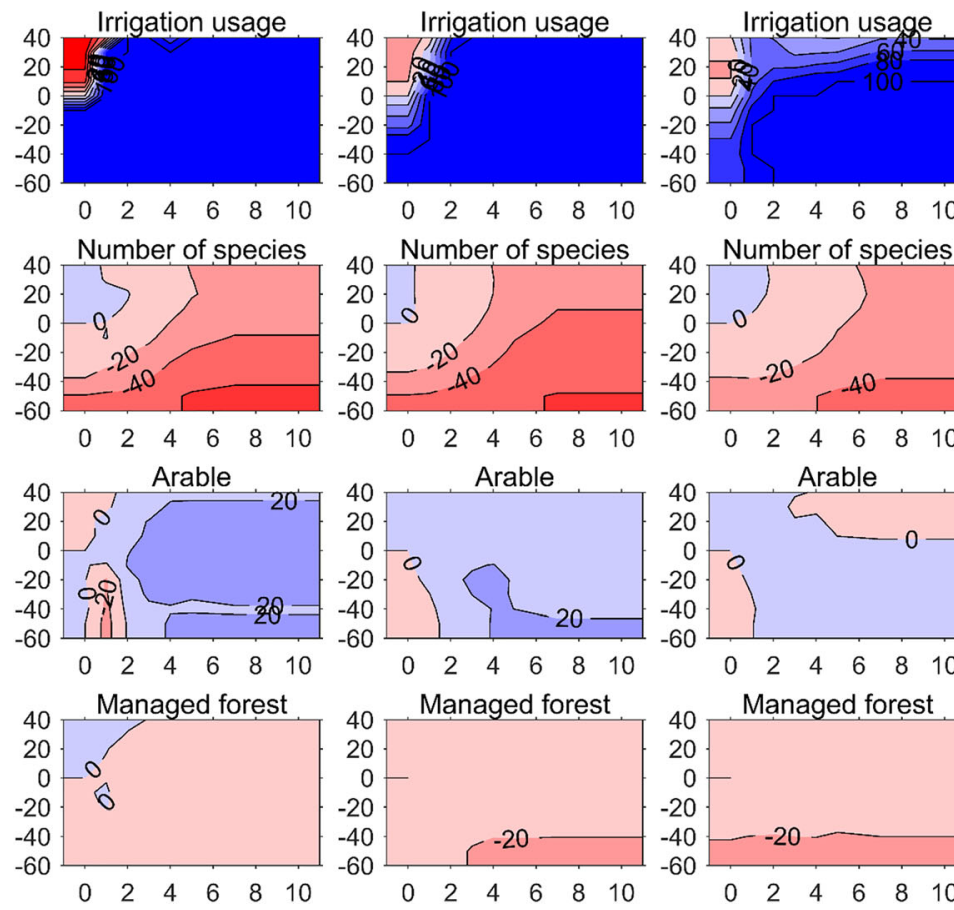

$\begin{array}{llllll}0 & 2 & 4 & 6 & 8 & 10\end{array}$$$
40
$$

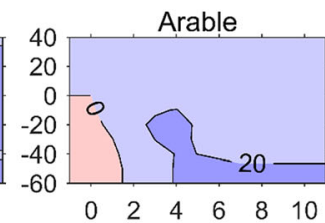

40
20
0
-20
-40
-60
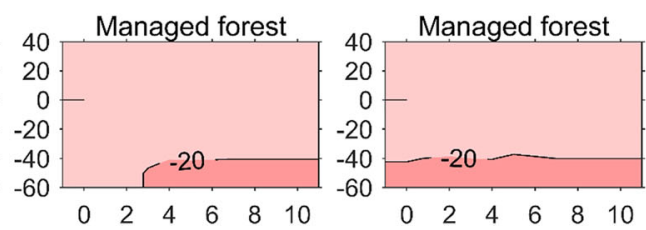
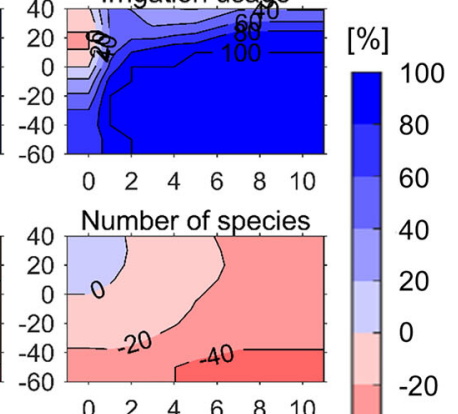

leading to reduced habitat space for non-agricultural (forest, montane, etc.) species. The proportional loss of species in the Czech Republic is higher than for the Continental region and Europe, reflecting the smaller area and reduced bioclimatic range.

\section{Climate change impacts}

Climate change impacts for the Czech Republic, without the influence of socio-economic changes, are shown in Fig. 3 for key IAP2 outputs (Table S6). Results are presented for each time period and RCP, and the uncertainty in the projections is shown by including all the GCM-RCM models of each ensemble (Table $\mathrm{S} 1$ ).

Generally, climate change impacts are, as expected, lower for the lower-end emission scenario (RCP2.6) and become more pronounced over time within the same emission scenario. Average rainfed wheat yields generally increase in the Czech Republic (Fig. 3) and Continental region (Fig. S4 of ESM), but decrease for Europe (Fig. S5 of ESM). However, there is uncertainty in the direction of change for many time periods in the Czech Republic due to climate model uncertainty. Average potato yields decrease for the projections of all RCPs and time periods to the extent that potatoes are no longer selected for some time period-RCP-climate model combinations (as shown by negligible or zero average yield). This reflects the loss of competitiveness of the Czech Republic for profitable potato cultivation, as potato yields remain largely constant in the Continental region (Fig. S4) and Europe (Fig. S5).

Irrigation usage increases as a consequence of both increased irrigation demand (caused by the warmer drier summer periods and increased arable areas) and the increased water availability which allows greater volumes to be allocated to agriculture (having allowed for the public, industrial, energy generation, and environmental water needs). The increased water demands are balanced by the increased water availability so that there are little changes in WEI over time in the Czech Republic.

The number of species with suitable climate and habitat space decreases slightly under RCP2.6, but further progressive decreases are projected over time with increasing emissions reflecting decreasing climate suitability for many species and future declines in some land-use classes within the Czech Republic, therefore restricting the habitat of some species. In particular, whilst there are increases in the area of intensive arable land and changes in the relative proportions of unmanaged and managed forests (increasing and 


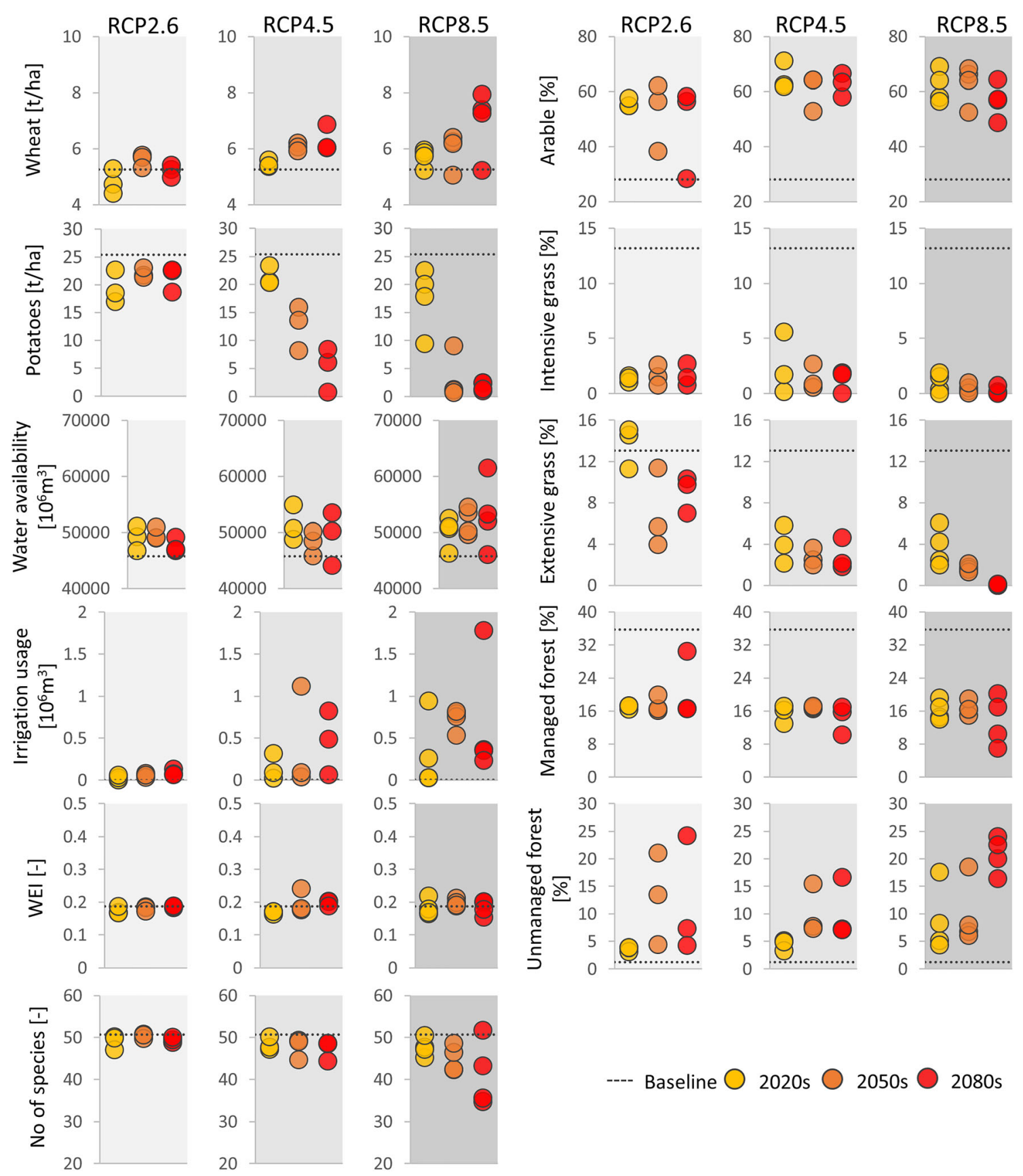

Fig. 3 Crop, water, biodiversity, and land-use simulations from Integrated Assessment Platform 2 (IAP), for the baseline and future time periods, aggregated for the Czech Republic. Results are shown for each

representative concentration pathway (RCP), with baseline socio-economics. Per time period, the dots represent the different models of the ensemble used in each RCP simulation

decreasing, respectively), there are major losses of grassland - to the point of virtually disappearing in the 2080s under RCP8.5. Both intensive and extensive grassland decrease strongly with increasing climate change and time in the Czech Republic and Continental Region, but intensive grassland only slightly reduces at the European level. As the IAP2 aims to meet net European food demand under climate change by expanding/contracting production areas based on profitability levels, arable agriculture in the Czech Republic

and Continental region generally becomes more profitable than dairy and livestock farming leading to land-use conversion, whereas dairying on intensive grassland maintains its profitability in other regions of Europe.

\section{Climate and socio-economic change impacts}

The response of key outputs to combined climate and socioeconomic scenarios for the end of the twenty-first century 
time-slice (2080s), reported per RCP for the Czech Republic, is shown in Fig. 4. All the GCM-RCM models of each ensemble are shown to depict the range of uncertainty in the projections. It is apparent that the inclusion of the socio-economic scenarios leads to a greater diversity of outcomes for the $2080 \mathrm{~s}$ than climate change alone.

First, looking at the agricultural indicators, wheat yields increase strongly within SSP4 and SSP5, which are both scenarios of strong technological and agronomic innovation, in contrast to the decreases in SSP3, where social and political break-down leads to productivity losses. Despite the innovation in SSP4 and SSP5, potato cultivation only remains profitable in the Czech Republic under SSP1, a scenario of increased European domestic production as the continent reduces food imports in order to reduce its external environmental burdens. This is the only SSP that leads to strong increases in the arable area in Europe in the 2080s (Fig. S8). Alternatively, in the Czech Republic, the arable area increases for at least one climate model for all RCP-SSP scenarios indicating that the country's arable agriculture is a relative

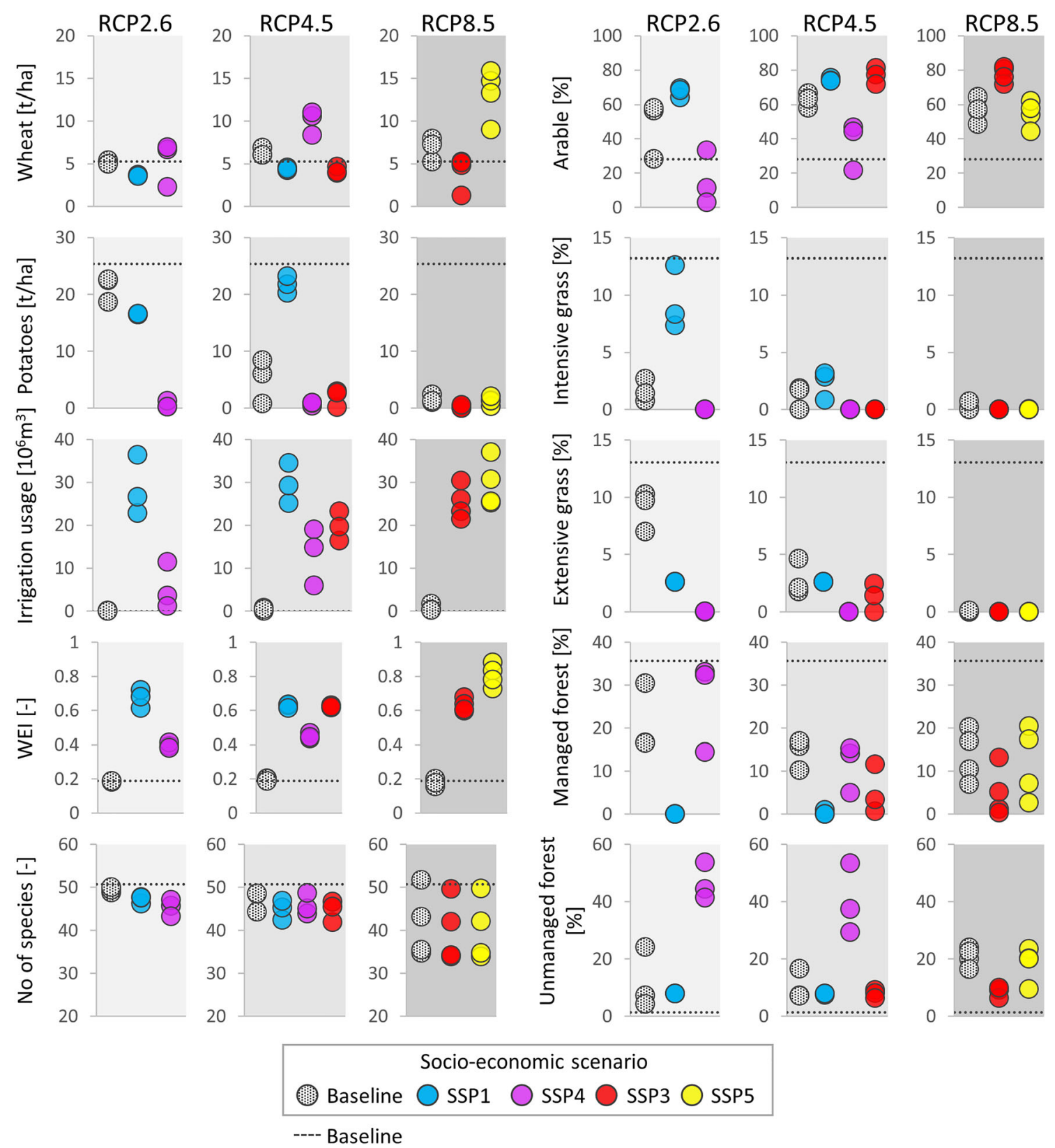

Fig. 4 Crop, water, biodiversity, and land-use simulations from Integrated Assessment Platform 2 (IAP), for the baseline (dashed line) and 2080s future time period (coloured dots), aggregated for the Czech Republic. For the 2080s, results are shown per representative concentration pathway (RCP), for each shared socio-economic pathway (SSP)xRCP scenario run. The dots of the same colour represent the different global climate model (GCM)-regional climate model (RCM) combinations of the ensemble used in each RCP simulation 
winner under most futures. As a consequence of this expansion in the arable area in the Czech Republic under the SSPs, there are large increases in irrigation usage compared with the projections forced with baseline socio-economics. The largest increases occur in SSP1 (under RCP2.6 and 4.5) due to the need to increase domestic food production and in SSP4 and 5 (under RCP8.5) where technological innovation drives down the cost of the irrigation, thereby making irrigated agriculture increasingly profitable compared with rainfed agriculture under the high-end climate change scenario.

Similarly to the climate change-only scenarios (Fig. 3), grassland agriculture declines under the SSPs except in SSP1 (Fig. 4) where the reduced dietary preference for red and white meat (Table S2) leads to increased demand for dairy products and consequently little change in the intensive grassland area. However, the expansion of arable areas and the increased demand for dairy products and therefore increased profitability of intensive grassland in SSP1 lead to a different spatial pattern of land-use changes compared with the other scenarios (Fig. S6).

In SSP1-RCP2.6, arable agriculture expands into the grassland areas and low elevation forest (Fig. S6). Consequently, the grassland areas displace much of the forest in the higher elevation areas near the northern, eastern, and south-western borders. In SSP3 and SSP5, the expansion of the arable area (Fig. 4) is similarly at the expense of the grassland areas and low elevation forest (Fig. 4 and Fig. S6), but the low profitability of Czech livestock farming in these scenarios compared with elsewhere in Europe means that the livestock farming is displaced from the country and forest remains. These large projected future changes in land-use in the Czech Republic due to the changing relative profitability of arable and grassland systems, relative to each other and to other parts of Europe, will have significant consequences for rural (agricultural and forestry) livelihoods and the country's landscape.

WEI shows only marginal changes under all RCPs combined with baseline socio-economics but increases to levels indicating severe water scarcity (WEI $>0.4$ ) for the Czech Republic under all socio-economic scenarios, although the underlying reasons for the increases differ between scenarios. For example, SSP5 is associated with the largest increase in WEI as a combination of large population and GDP increases, low behavioural interest in water saving, and low environmental regulation of abstraction leading to large water abstraction increases. In SSP3, the effects of the decreases in population and GDP on water demand are offset by low behavioural and technological water saving and reduced irrigation efficiency. SSP4 has the smallest impact on increasing WEI, as high levels of technological water savings offset much of the increased water demands. Similar changes in WEI are seen in the Continental region (Fig. S7 of ESM) and also Europe (Fig. S8 of ESM), albeit to a lower level due to the moderating influence of the wetter northern and western regions.

The number of simulated species present in the Czech Republic is projected to decrease in all three climate change scenarios, with the impacts and uncertainty getting more pronounced for the higher-end scenarios due to greater changes in a species' climate and habitat space. The relative consistency across the SSPs for the same RCP reflects the common major changes in land-use across the SSPs (expansion of intensive arable and reduction/loss of grassland systems) despite SSP differences in the proportions of arable and forest land-uses (e.g. lower arable and higher forest areas in SSP4, compared with the other SSPs in Fig. 4).

\section{Discussion}

We have applied a trans-European integrated modelling platform (the IMPRESSIONS IAP2) to understand the consequences of climate and socio-economic change for the Czech Republic. First, we have shown that a range of outputs from the IAP2 can be acceptably validated at the nationalscale against multiple indicators (land-use, crop yield, and crop area). Second, we have carried out a novel nationalscale impact assessment that takes account of the consequences of cross-sectoral interactions at national to continental scales. Previous regional-scale applications of IAP2 (Clarke et al. 2017) did not focus on the inter-scale interactions of reported impacts. Moreover, previous national-scale climate change impact assessments for the Czech Republic have focused on single 'sectors' (e.g. hydrology by Dvorak et al. 1997; Dubrovsky et al. 2009; Hanel et al. 2012; agriculture by Trnka et al. 2004, 2009; Lorencová et al. 2013), without accounting for the impact flows between sectors and regions. Consequently, modelled impacts within a country can be overor under-estimated if the systemic footprint of climate change, in terms of feedbacks and interactions with other sectors (Harrison et al. 2016) and cross-scale dependencies within the wider geographical area, is not taken into account. To the authors' knowledge, this is the first time an integrated crosssectoral assessment of climate change and socio-economic impacts for the Czech Republic, taking account of interactions with the rest of Europe, has been performed.

IRSs have been previously used to understand model response to simple system perturbations (e.g. Prudhomme et al. 2010; Remesan and Holman 2015; Fronzek et al. 2018). Here we use them to provide a first indication of the scale interdependencies of the modelled impacts under precipitation and temperature perturbations, by comparing national-, regional-, and continental-scale responses. Subtle but systematic scaledependent differences were found between some indicator responses in the Czech Republic, Continental region, and Europe. These differences included slightly better response of average 
crop yields in the Czech Republic and Continental region compared with Europe and greater increases in the benefits of irrigated compared with rainfed cropping for farm profitability in the Czech Republic compared with both the Continental region and Europe (as seen in the much greater increase in irrigation usage). Such systematic scale-dependent differences meant that arable agriculture in the Czech Republic was projected to have a comparative profitability advantage over Europe as a whole across much of the IRS, although changing interannual variability which can be crucial for agricultural production is not addressed by the IAP2. Consequently, whilst the overall arable area in Europe was little changed across the IRS, the simulated arable area in the Czech Republic expanded by up to more than $20 \%$ at the expense of production in other parts of Europe (Fronzek et al. 2018). A partial consequence of these scale interdependencies in land-use changes is that the scenarioneutral climate changes lead to more pronounced negative impacts on biodiversity in the Czech Republic.

However, the scenario-neutral analysis does not show the full picture of scale interdependencies as these largely depend on socio-economic factors such as food imports and agricultural demands. Model projections based on combined climate and socio-economic scenarios lead to a far greater diversity of outcomes for the Czech Republic for the 2080s than those associated with climate change scenarios alone. Future changes in the socio-economic conditions of countries and continents will affect all aspects of human systems, e.g. levels of agronomic innovation, food demand (through changing population numbers, food imports, and dietary preferences), water demand (through technology uptake and personal behaviour), and regulation (through spatial planning and environmental protection). The impact of these factors on spatial patterns of European food productivity, food and water demands, and environmental constraints across Europe leads to complex spatially varying changes in the model outputs for the Czech Republic.

The projected changes that are largely consistent in their direction, if not magnitude, of change across most scenario combinations for the Czech Republic are an expansion of arable land, reduction or loss of grasslands, reduction in area of managed forests and increase in the area of unmanaged forest, water scarcity, and a reduction in the number of species. Some of these impacts would be expected from the direct impacts of climate and socio-economic change acting solely within the Czech Republic; however, the consideration of the country level interactions within the greater geographical area can reveal different patterns for some indicators. Koutroulis et al. (2018), in a pan-European assessment of water availability with no spatial interactions, also found increases in mean water availability for the Czech Republic under climate and socio-economic change. They also found decreases in freshwater vulnerability, indicating less water scarcity at the country level. However, we find that the country moves towards extreme water scarce conditions due largely to increases in non-agricultural water use (driven by socio-economic change), leading to greatly constrained increases in irrigation usage and a projected expansion of rainfed arable land in the Czech Republic. On the land-use aspect, Trnka et al. (2009) also report declines in grasslands under climate change; however, taking into account the growing importance of the Czech Republic as a crop-growing region for Europe, our results show far more dramatic declines for grassland areas.

Our findings can provide valuable insights to support adaptation actions and policy measures in the Czech Republic and more broadly. The significant changes in simulated land-use in response to future climate and socio-economic change (e.g. expansion of arable farming, reduction or loss of grassland systems, and the reduction in managed forestry) imply significant changes to the rural economy, landscape heterogeneity and character, water quality, and habitat availability and connectivity. In such circumstances, future policy will need to support measures for a sustainable transition (Blanco et al. 2017; Brown et al. 2018) that will also allow the protection of valuable ecosystem services, such as measures to prevent/ minimise soil erosion, preserve key characteristics of the landscape that are valued for tourism, and to support biodiversity. Such measures include establishing protected areas for key habitats and biodiversity corridors to support migration of species within and into the Czech Republic (Keeley et al. 2018). However, to develop effective policies, more locally specific considerations - which are not covered by the existing modelling platform-should be taken into account. For example, the projected conversion of forest to arable land could, in reality, be limited by land ownership conflicts and/or local topography of the forest terrain.

Our analysis shows strong signals of change due to climate and socio-economic change, with the land-water-biodiversity system in the Czech Republic being particularly sensitive to socio-economic factors, reinforcing the findings of Harrison et al. (2018) and Fronzek et al. (2018). Socio-economic change therefore becomes the most important source of uncertainty in the future projections due to its dominant influence on all aspects of demand for, production of, trade-in and regulation of natural resources. It is imperative therefore that future impact assessments avoid either neglecting socio-future economic change and its uncertainties or assuming some form of Business-As-Usual trends. Immediate policy priorities should aim to transition the Czech and European societies and economies towards more sustainable futures (Hölscher et al. 2018; Tàbara et al. 2018) that reduce the systemic nonclimate pressures from unsustainable behaviours, thereby increasing the effectiveness of adaptation actions to reduce climate impacts and support a positive change in the system (Dunford et al. 2015). 


\section{Conclusion}

We used a novel approach to study the impacts of climate and socio-economic change at the national level of the Czech Republic, accounting for trans-national and crosssectoral interactions. The major impacts, consistent across most scenarios, are the expansion of arable land, reduction or loss of grasslands and managed forests, increased water scarcity, and loss of species. These impacts are partially driven by the increased importance of the Czech Republic as a crop-growing region for Europe, due to an increasing competitive advantage within the continent.

Our analysis highlights the importance of considering wider geographical domain interactions in integrated national-scale assessments of climate and socio-economic change, as they may have considerable impacts on nationallevel results. Moreover, such an approach can reveal the changing role of a country within its wider geographical and economic area, which is important to inform relevant measures for adaptation. Finally, the importance of socioeconomic drivers highlights the opportunity for adaptation actions to alleviate negative impacts and provide support for climate resilient and sustainable development.

Funding information The research leading to these results has received funding from the European Commission Seventh Framework Programme under Grant Agreement No. 603416 (The IMPRESSIONS project; Impacts and risks from higher-end scenarios: strategies for innovative solutions) and SustES - Adaptation strategies for sustainable ecosystem services and food security under adverse environmental conditions (CZ.02.1.01/0.0/0.0/16_019/0000797).

Open Access This article is distributed under the terms of the Creative Commons Attribution 4.0 International License (http:// creativecommons.org/licenses/by/4.0/), which permits unrestricted use, distribution, and reproduction in any medium, provided you give appropriate credit to the original author(s) and the source, provide a link to the Creative Commons license, and indicate if changes were made.

\section{References}

Blanco V, Holzhauer S, Brown C, Lagergren F, Vulturius G, Mats L, Rounsevell MDA (2017) The effect of forest owner decision-making, climatic change and societal demands on land-use change and ecosystem service provision in Sweden. Ecosyst Serv 23:174-208. https://doi.org/10.1016/j.ecoser.2016.12.003

Brown C, Brown E, Murray-Rust D, Cojocaru G, Savin C, Rounsevell M (2015) Analysing uncertainties in climate change impact assessment across sectors and scenarios. Clim Chang 128:293-306. https://doi. org $/ 10.1007 / \mathrm{s} 10584-014-1133-0$

Brown C, Holzhauer S, Metzger MJ, Paterson JS, Rounsevell M (2018) Land managers' behaviours modulate pathways to visions of future land systems. Reg Environ Chang 18:831-845. https://doi.org/10. 1007/s10113-016-0999-y

Clarke L, Rounsevell M, Dunn M, Capela Lourenço T, Tàbara D, Pinter L, Juhasz-Horvath L, Gaál Z, Holman I, Frantzeskaki N, Jäger J, Christensen JH, Madsen MS, Pedde S, Cojocaru G, Lobanova A, Li
S, Bugmann H, Snell R, Lafond V, Harrison PA, Fronzek S, Takahashi K, Honda Y, Ito A, Tanaka A, Yoshikawa M, Janes V (2017) Climate change impacts, adaptation and vulnerability model applications in three regional to local scale case studies in Europe. EU FP7 IMPRESSIONS Project Deliverable D3C:2

Czech Statistical Office (2018) Statistical yearbook of the Czech Republic, p 2018

De Meij A, Zittis G, Christoudias T (2018) On the uncertainties introduced by land cover data in high-resolution regional simulations. Meteorog Atmos Phys. https://doi.org/10.1007/s00703-018-0632-3

Dubrovsky M, Svoboda MD, Trnka M, Hayes MJ, Wilhite DA, Zalud Z, Hlavinka P (2009) Application of relative drought indices in assessing climate-change impacts on drought conditions in Czechia. Theor Appl Climatol 96:155-171. https://doi.org/10. 1007/s00704-008-0020-x

Dunford R, Harrison PA, Jäger J, Rounsevell MDA, Tinch R (2014) Exploring climate change vulnerability across sectors and scenarios using indicators of impacts and coping capacity. Clim Chang 128: 339-354. https://doi.org/10.1007/s10584-014-1162-8

Dunford RW, Smith AC, Harrison PA, Hanganu D (2015) Ecosystem service provision in a changing Europe: adapting to the impacts of combined climate and socio-economic change. Landsc Ecol 30: 443-461. https://doi.org/10.1007/s10980-014-0148-2

Dvorak V, Hladny J, Kasparek L (1997) Climate change hydrology and water resources impact and adaptation for selected river basins in the Czech Republic. Clim Chang 36:93-106. https://doi.org/10.1023/A: 1005384120954

EEA (2018) National climate change vulnerability and risk assessments in Europe, 2018. European Environment Agency. Luxembourg: Pulications Office of the European Union, 2018. doi: https://doi. org/10.2800/348489

Eitzinger J, Trnka M, Semeradova D, Thaler S, Svobodova E, Hlavinka P, Siska B, Takac J, Malatinska L, Novakova M, Dubrovsky M, Zalud Z (2012) Regional climate change impacts on agricultural crop production in Central and Eastern Europe - hotspots, regional differences and common trends. J Agric Sci 151:787-812. https://doi.org/ 10.1017/S0021859612000767

Frolking S, Xiao X, Zhuang Y, Salas W, Li C (1999) Agricultural landuse in China: a comparison of area estimates from ground-based census and satellite-borne remote sensing. Glob Ecol Biogeogr 8: 407-416. https://doi.org/10.1046/j.1365-2699.1999.00157.x

Fronzek S, Carter TR, Pirttioja N, Alkemade R, Audsley E, Bugmann H, Florke M, Holman I, Honda Y, Ito A, Janes-Bassett V, Lafond V, Leemans R, Mokrech M, Nunez S, Sandars D, Snell R, Takahashi K, Tanaka A, Wimmer F, Yoshikawa M (2018) Determining sectoral and regional sensitivity to climate and socio-economic change in Europe using impact response surfaces. Reg Environ Chang 19: 679-693. https://doi.org/10.1007/s10113-018-1421-8

Hanel M, Vizina A, Máca P, Pavlásek J (2012) A multi-model assessment of climate change impact on hydrological regime in the Czech Republic. J Hydrol Hydromehanics 60:152-161. https://doi. org/10.2478/v10098-012-0013-4

Harrison PA, Dunford RW, Holman IP, Rounsevell MDA (2016) Climate change impact modelling needs to include cross-sectoral interactions. Nat Clim Chang 6:885-890. https://doi.org/10.1038/ nclimate 3039

Harrison PA, Dunford RW, Holman IP, Cojocaru G, Madsen MS, Chen PY, Pedde S, Sandars D (2018) Differences between low-end and high-end climate change impacts in Europe across multiple sectors. Reg Environ Chang 19:1-15. https://doi.org/10.1007/s10113-0181352-4

Harrison PA, Holman IP, Berry PM (2015) Assessing cross-sectoral climate change impacts, vulnerability and adaptation: an introduction to the CLIMSAVE project. Clim Chang 128:153-167. https://doi. org/10.1007/s10584-015-1324-3 
Harrison PA, Holman IP, Cojocaru G, Kok K, Kontogianni A, Metzger MJ, Gramberger M (2013) Combining qualitative and quantitative understanding for exploring cross-sectoral climate change impacts, adaptation and vulnerability in Europe. Reg Environ Chang 13:761780. https://doi.org/10.1007/s10113-012-0361-y

Holman I, Audsley E, Berry P, Brown C, Bugmann H, Clarke L, Gojocaru G, Dunford R, Fronzek S, Harrison PA, Honda Y, Janes V, Kovats S, Lafond V, Lobanova A, Madsen MS, Mokrech M, Nunez S, Pedde S, Sandars D, Savin C, Wimmer F (2017) Modelling climate change impacts, adaptation and vulnerability in Europe. IMPRESSIONS Deliverable D3B:2 Available from www. impressions-project.eu

Hölscher K, Frantzeskaki N, Loorbach D (2018) Steering transformations under climate change: capacities for transformative climate governance and the case of Rotterdam, the Netherlands. Reg Environ Chang 50:1-15. https://doi.org/10.1007/s10113-018-1329-3

IPCC (2014) Climate Change 2014: Impacts, adaptation, and vulnerability. Part A: global and sectoral aspects. Contribution of working group II to the fifth assessment report of the intergovernmental panel on climate change [Field CB, Barros VR, Dokken DJ, Mach KJ, Mastrandrea MD, Bilir TE, Chatterjee M, Ebi KL, Estrada YO, Genova RC, Girma B, Kissel ES, Levy AN, MacCracken S, Mastrandrea PR, White LL (eds.)]. Cambridge University Press, Cambridge, United Kingdom and New York, NY, USA, 1-34 pp

Jacob D, Petersen J, Eggert B, Alias A, Christensen OB, Bouwer LM, Braun A, Colette A, Déqué M, Georgievski G, Georgopoulou E, Gobiet A, Menut L, Nikulin G, Haensler A, Hempelmann N, Jones C, Keuler K, Kovats S, Kröner N, Kotlarski S, Kriegsmann A, Martin E, van Meijgaard E, Moseley C, Pfeifer S, Preuschmann S, Radermacher C, Radtke K, Rechid D, Rounsevell M, Samuelsson P, Somot S, Soussana JF, Teichmann C, Valentini R, Vautard R, Weber B, Yiou P (2014) EURO-CORDEX: new high-resolution climate change projections for European impact research. Reg Environ Chang 14:563-578. https://doi.org/10.1007/s10113-0130499-2

Kebede AS, Dunford R, Mokrech M, Audsley E, Harrison PA, Holman IP, Nicholls RJ, Rickebusch S, Rounsevell MDA, Sabaté S, Sallaba F, Sanchez A, Savin C, Trnka M, Wimmer F (2015) Direct and indirect impacts of climate and socio-economic change in Europe: a sensitivity analysis for key land- and water-based sectors. Clim Chang 128:261-277. https://doi.org/10.1007/s10584-014-1313-y

Keeley ATH, Basson G, Cameron DR, Heller NE, Huber PR, Schloss CA, Thorne JH, Merenlender AM (2018) Making habitat connectivity a reality. Conserv Biol 32:1221-1232. https://doi.org/10.1111/ cobi. 13158

Kjellström E, Nikulin G, Hansson U, Strandberg G, Ullerstig A (2011) 21st century changes in the European climate: uncertainties derived from an ensemble of regional climate model simulations. Tellus Ser A Dyn Meteorol Oceanogr 63:24-40. https://doi.org/10.1111/j. 1600-0870.2010.00475.x

Kok K, Pedde S, Gramberger M, Harrison PA, Holman IP (2018) New European socio-economic scenarios for climate change research: operationalising concepts to extend the Shared Socioeconomic Pathways. Reg Environ Chang 19:643-654. https://doi.org/10. 1007/s10113-018-1400-0

Koláŕ T, Čermák P, Trnka M, Zid T, Rybnicek M (2017) Temporal changes in the climate sensitivity of Norway spruce and European beech along an elevation gradient in Central Europe. Agric For Meteorol 239:24-33. https://doi.org/10.1016/j.agrformet.2017.02.028

Koutroulis AG, Papadimitriou LV, Grillakis MG, Tsanis IK, Wyser K, Betts RA (2018) Freshwater vulnerability under high end climate change. A pan-European assessment. Sci Total Environ 613-614: 271-286. https://doi.org/10.1016/j.scitotenv.2017.09.074

Kovats RS, Valentini R, Bouwer LM, Georgopoulou E, Jacob D, Martin E, Rounsevell M, Soussana J-F (2014) Europe. In: Climate change 2014: Impacts, adaptation, and vulnerability. Part B: regional aspects. contribution of working group II to the fifth assessment report of the intergovernmental panel on climate change [Barros, V.R., C.B. Field, D.J. Dokken, M.D. Mastrandrea, K.J. Mach, T.E. Bilir, M. Chatterjee, K.L. Ebi, Y.O. Estrada, R.C. Genova, B. Girma, E.S. Kissel, A.N. Levy, S. MacCracken, P.R. Mastrandrea, and L.L.White (eds.)]. Cambridge University Press, Cambridge, United Kingdom and New York, NY, USA, pp. 1267-1326

Kyselý J, Beranová R (2009) Climate-change effects on extreme precipitation in central Europe: uncertainties of scenarios based on regional climate models. Theor Appl Climatol 95:361-374. https://doi.org/ 10.1007/s00704-008-0014-8

Kyselý J, Gaál L, Beranová R (2011) Projected changes in flood-generating precipitation extremes over the Czech Republic in high-resolution regional climate models. J Hydrol Hydromechanics 59:217-227. https://doi.org/10.2478/v10098-011-0018-4

Lorencová E, Frélichová J, Nelson E, Vackar D (2013) Past and future impacts of land use and climate change on agricultural ecosystem services in the Czech Republic. Land Use Policy 33:183-194. https://doi.org/10.1016/j.landusepol.2012.12.012

Lorencová EK, Whitham CEL, Bašta P, Harmackova ZV, Stepanek P, Zahradnicek P, Farda A, Vackar D (2018) Participatory climate change impact assessment in three Czech cities: the case of heatwaves. Sustain 10:1-21. https://doi.org/10.3390/su10061906

Lučan RK, Weiser M, Hanák V (2013) Contrasting effects of climate change on the timing of reproduction and reproductive success of a temperate insectivorous bat. J Zool 290:151-159. https://doi.org/ $10.1111 /$ jzo. 12021

Machar I, Vlckova V, Bucek A, Vrublova K, Filippovova J, Brus J (2017) Environmental modelling of climate change impact on grapevines: case study from the Czech Republic. Polish J Environ Stud 26: 1927-1934. doi: https://doi.org/10.15244/pjoes/68886

Madsen MS, Maule CF, Christensen JH, Fonzek S, Carter T (2016) IMPRESSIONS climate scenarios. EU FP7 IMPRESSIONS Project Deliverable D2:3

Metzger MJ, Bunce RGH, Jongman RHG, Mucher CA, Watkins JW (2005) A climatic stratification of the environment of Europe. Glob Ecol Biogeogr 14:549-563. https://doi.org/10.1111/j.1466822X.2005.00190.x

New M, Lister D, Hulme M, Makin I (2002) A high-resolution data set of surface climate over global land areas. Clim Res 21:1-25. https:// doi.org/10.3354/cr021001

O’Neill BC, Kriegler E, Ebi KL, Kemp-Benedict E, Riahi K, Rothman DS, van Ruijven BJ, van Vuuren DP, Birkmann J, Kok K, Levy M, Solecki W (2017) The roads ahead: narratives for shared socioeconomic pathways describing world futures in the 21 st century. Glob Environ Chang 42:169-180. https://doi.org/10.1016/j.gloenvcha. 2015.01.004

Pedde S, Kok K, Onigkeit J, Brown C, Holman I, Harrison PA (2018) Bridging uncertainty concepts across narratives and simulations in environmental scenarios. Reg Environ Chang 19:1-12. https://doi. org/10.1007/s10113-018-1338-2

Pérez-Hoyos A, García-Haro FJ, San-Miguel-Ayanz J (2012) Conventional and fuzzy comparisons of large scale land cover products: application to CORINE, GLC2000, MODIS and GlobCover in Europe. ISPRS J Photogramm Remote Sens 74:185-201. https:// doi.org/10.1016/j.isprsjprs.2012.09.006

Prudhomme C, Wilby RL, Crooks S, Kay AL, Reynard NS (2010) Scenario-neutral approach to climate change impact studies: application to flood risk. J Hydrol 390:198-209. https://doi.org/10.1016/ j.jhydrol.2010.06.043

Remesan R, Holman IP (2015) Effect of baseline meteorological data selection on hydrological modelling of climate change scenarios. J Hydrol 528:631-642. https://doi.org/10.1016/j.jhydrol.2015.06.026

Rojas R, Feyen L, Watkiss P (2013) Climate change and river floods in the European Union: socio-economic consequences and the costs 
and benefits of adaptation. Glob Environ Chang 23:1737-1751. https://doi.org/10.1016/j.gloenvcha.2013.08.006

Rulfová Z, Beranová R, Kyselý J (2017) Climate change scenarios of convective and large-scale precipitation in the Czech Republic based on EURO-CORDEX data. Int J Climatol 37:2451-2465. https://doi. org/10.1002/joc. 4857

Stepanek P, Zahradnicek P, Farda A, Skalak P, Trnka M, Meitner J, Rajdl K (2016) Projection of drought-inducing climate conditions in the Czech Republic according to Euro-CORDEX models. Clim Res 70: 179-193. https://doi.org/10.3354/cr01424

Tàbara JD, Cots F, Pedde S, Holscher K, Kok K, Lovanova A, Capela Lourenco T, Frantzeskaki N, Etherington J (2018) Exploring institutional transformations to address high-end climate change in Iberia. Sustain 10. https://doi.org/10.3390/su10010161

Trnka M, Dubrovsky M, Zalud Z (2004) Climate change impacts and adaptation strategies in spring barley production in the Czech Republic. Clim Chang 64:227-255. https://doi.org/10.1023/ B:CLIM.0000024675.39030.96

Trnka M, Eitzinger J, Hlavinka P, Dubrovsky M, Semeradova D, Stepanek P, Thaler S, Zalud Z, Mozny M, Formayer H (2009)
Climate-driven changes of production regions in Central Europe. Plant Soil Environ 55:. doi: https://doi.org/10.17221/1017-PSE

Trnka M, Semerádová D, Novotný I, Dumbrovsky M, Drbal K, Pavlik F, Vopravil J, Stepankova P, Vizina A, Balek J, Hlavinka P, Bartosova L, Zalud Z (2016) Assessing the combined hazards of drought, soil erosion and local flooding on agricultural land: a Czech case study. Clim Res 70:231-249. https://doi.org/10.3354/cr01421

van Vuuren DP, Carter TR (2014) Climate and socio-economic scenarios for climate change research and assessment: reconciling the new with the old. Clim Chang 122:415-429. https://doi.org/10.1007/ s10584-013-0974-2

van Vuuren DP, Edmonds J, Kainuma M, Riahi K, Thomson A, Hibbard K, Hurtt GC, Kram T, Krey V, Lamarque JF, Masui T, Meinshausen M, Nakicenovic N, Smith SJ, Rose SK (2011) The representative concentration pathways: an overview. Clim Chang 109:5-31. https://doi.org/10.1007/s10584-011-0148-z

Publisher's note Springer Nature remains neutral with regard to jurisdictional claims in published maps and institutional affiliations. 